\title{
Chapter 3. Determinants of Cross-Border M\&A and Shareholder Wealth Effects in a Globalized World
}

\author{
Eugene Nivorozhkin
}

\begin{abstract}
We analyse theoretical insights and empirical regularities related to factors determining the cross-border mergers and acquisitions $(M \& A)$ and impact of $M \& A$ on shareholder value of acquires and targets. The analysis of cross-border $M \& A$ is a relatively new subject and only recently received rigorous attention in academic research. Within this nascent literature, the survey pays particular attention to the emerging markets, which, in line with their growing role of in the global economy, became an increasingly important arena for cross-border $M \& A$. The existing evidence point out to prevailing challenges in studying crossborder M\&A by emerging markets firms. The results are often contradictory, and tend to focus on a single country falling short of formally testing existing theories or developing comprehensive theories for emerging economies. We show that the type of factors increasing the value enhancing effects of $M \& A$ tend to be similar to the factors affecting the likelihood of $M \& A$ transactions. The related methodological challenges for the existing studies are related to strong evidence with respect to non-random selection of acquisition targets, which, among other "selection issues", has important implications for choosing counterfactual evidence in order to appropriately compare pre-and post-acquisition performance of firms.
\end{abstract}




\subsection{Introduction}

The global market for mergers and acquisitions (M\&A) has been steadily expanding in the recent years, recovering from the slump caused by the Global Financial Crisis of 2008-9, with both the number and the volume of transactions reaching the record-high levels (see Figure 1). Nevertheless, the value of global M\&A transitions as a share of GDP tended to remain below the levels observed in the pre-crisis years. As in the past, the increasing number of the worldwide M\&A could be attributed to the dynamic nature of international trade and the consolidations of industries and regions (Shimizu et al., 2004). Moreover, the increasing globalization of business has dramatically increased the opportunities and pressures to engage in cross-border M\&A in a turbulent and continuously changing environment (Hitt, 2000). While the majority of M\&A involved two firms within the same country, the share of crossborder transactions value in the total value of $M \& A$ deals remained significant at 31 percent in 2015, similar to what was observed in 2011 and below the 39 percent observed in 2007 (KPMG, 2016).

Given the increasing number of cross-border M\&A and their growing importance in the global market, this survey will focus on factors determining the cross-border M\&A activities the issue which only recently received rigorous attention in academic research. We will also look at whether cross-border M\&A transactions created wealth for firms' shareholders and whether the magnitude of this wealth creation and its distribution between acquiring and target firms' shareholders was different comparing to domestic M\&A deals. The survey will pay particular attention to the emerging markets, which became an increasingly important arena for M\&A, in line with their growing role in the global economy.

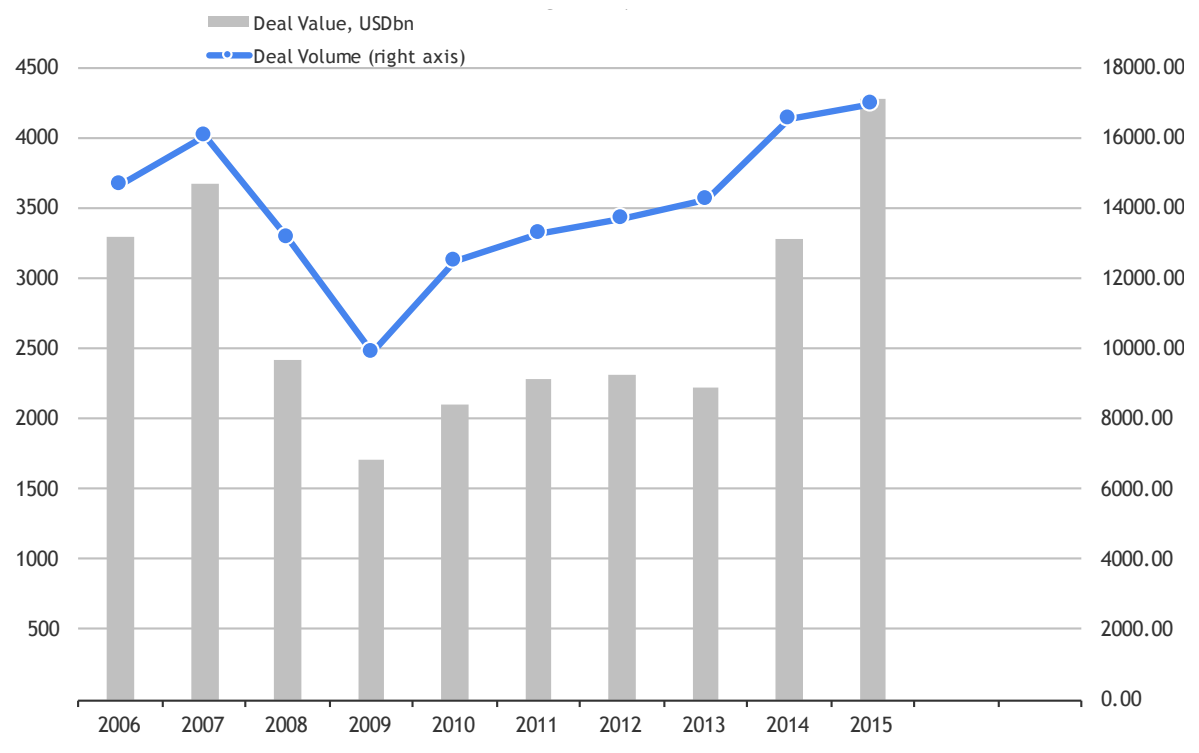

Fig. 1 Global M\&A deals (Source: KPMG (2016))

Understanding factors affecting the value and the volume of mergers and acquisitions is of great importance from both practical and academic perspective. As many other mechanisms employed in the market-based economic systems, M\&A are expected to contribute to efficient allocation of scarce resources in the economy by facilitating reallocation of control over companies, such that corporate assets are channelled toward their best possible use. Success or failure of combining companies through M\&A to achieve certain strategic and business 
objectives is important not only for the companies themselves but also has important implications for workers, managers, competitors, communities, and the economy as a whole (Sudarsanam, 2003). M\&A are a multi-stage process characterised by a number of diverse problems and challenges for the firms involved. The historical developments in the market for corporate control indicate that the external context in which M\&A take place is of crucial importance for understanding the issues affecting transactions. This external environment for the M\&A transactions extends beyond purely economic considerations and includes political, sociological, and technological factors.

From the theoretical perspective, the foreign market entry of an acquirer is likely to be driven by desire to utilise its comparative advantage in exploiting market imperfections (e.g., Buckley and Casson, 1976; Morck and Yeung, 1992; Wilson, 1980). The benefits of integrating acquirer's business with another firm are typically accrued through internalization, synergy, and risk diversification and expected to create wealth for both acquirer and target-firm shareholders (Kang, 1993; Markides and Ittner, 1994; Morck and Yeung, 1991, 1992).

The empirical evidence reviewed in this paper seem to indicate that overall the crossborder M\&A are more likely to create value and produce gain for both parties involved in the transaction comparing to the domestic M\&A, which are typically categorised by positive returns for the seller and negative or neutral returns for the buyer, with non-existing or marginally positive combined returns.

The surveyed literature also provides strong evidence with respect to non-random selection of acquisition targets and highlights unique challenges represented by the crossborder M\&A deals which tend to involve firms from the countries with different economic, institutional, and cultural environments.

The remainder of the article is organised as follows. Section 2 reviews factors associated with the occurrence of the cross-border M\&A deals. Section 3 looks at what factors tend to important for success of M\&A in terms of creating shareholder value. Section 4 offers concluding remarks.

\subsection{Determinants of Cross-border M\&A}

Historically, M\&A activities tend to exhibit distinct wave patterns within countries and globally, with bursts in terms of both volume and value of transactions followed by periods of relative inactivity (Gilson and Black, 1995). Although the determinants of M\&A waves are still not fully understood, there are several stylised facts identified in the literature. The contextual developments accompanying M\&A waves tend to affect the competitive advantage of firms or open up new markets. These developments typically include periods of high economic growth, episodes of recovery from economic recession and rising stock market, as well as discovery of new technologies (e.g., Gort, 1969; Bannock, 1990; Jensen, 1997). Merger waves also tend to depend on the political, regulatory, institutional, and demographic changes (e.g., Bhagat et. al, 1990; Shleifer and Vishny, 1991; Mitchell and Mulherin, 1996, Andrade et. al, 2001). Importantly, the effect of various factors on M\&A activities tend to vary across industries and there is evidence of industry clustering of these activities (e.g., Mitchell and Mulherin, 1996; Shoenberg and Reeves, 1999). 
Andrade et. al (2001) point out that while research on M\&A activities has revealed a lot about their trends and characteristics over the last century, research success on the issue of why mergers occur has been more limited. A number of complementary economic theories have been able to explain some of the mergers over the last century and helped to understand the M\&A drivers. The leading theories supported by empirical evidence highlighted factors such as efficiency-related reasons for M\&A, which typically involve economies of scale or other "synergies"; attempts to create market power, for example by forming monopolies or oligopolies; market discipline, exemplified by the removal of incompetent management of a target company; "empire building" incentives by acquirer management to "over-expand" and other agency costs; and diversification strategies, involving exploiting internal capital markets and managing risk for undiversified managers. Importantly, these reasons for M\&A appear to be relevant only in certain time periods.

Andrade et. al (2001) argue that the historically observed merger waves and industry clustering of M\&A activities in the U.S. documented in Mitchell and Mulherin (1996), suggest that mergers are likely to occur as a reaction to unexpected (and hence largely unpredictable) shocks to industry structure, the view which is also consistent with the prevailing intuition of practitioners and analysts. To this extent, the results in Andrade et. al (2001) indicate that M\&A activities in the U.S. in the 1990s continued to be clustered by industry and were increasingly and predominantly influenced by an industry shock represented by deregulation.

Although the dynamics of cross-border M\&A tend to be similar to those of domestic M\&A, they also involve unique challenges, as countries have different economic, institutional (i.e., regulatory), and cultural environments (Hofstede, 1980; House et al., 2002). Cross-border M\&A can facilitate access to new and profitable markets and expand the market for a firm's existing products. For example, international M\&A are often used to maintain market share and avoid possible future threats, with suppliers strategically following the international expansion of their counterparties who could otherwise find alternative foreign suppliers with potential negative implications for the domestic market share of the existing supplier (Martin et al., 1998) Moreover, acquisitions of foreign firms often help the acquirer to obtain new knowledge and capabilities.

In general, country-, industry-, and firm-level factors, related to both to the acquiring and to the target firm are important determinants of cross-border M\&A. The important national and industry level factors are capital, labour, and natural resource endowments. Moreover, institutional variables such as the legal, political, and cultural environment also tend to play a crucial role. At the firm level, the important task is to identify and evaluate potential targets, so they can be effectively integrated with the acquiring firm in the post-acquisition period to realize the potential value of investment.

A recent study by Erel et. al (2012) focuses on international factors influencing the decision of firms to merge. These factors include cultural or geographic differences, governance-related differences across countries, and imperfect integration of capital markets across countries. The authors use a sample of 56,978 cross-border mergers occurring between 1990 and 2007, and involving both public and private companies, to estimate the factors that affect the likelihood that firms from any pair of countries merge in a particular year.

A number of relevant factors appear to significantly explain the cross-sectional pattern of mergers. The first set of factors is related to attractive valuation of a target company as a motivation for cross-border merger, where currency and capital market valuation differences 
can arise due to imperfect integration between countries. The importance of changes in relative valuation which are likely to lead to acquisitions tend to be supported by positive effects of the 12-month real exchange rate return difference between the two countries' currencies, and 12month stock return difference of the country indices in local currency, with both indicators measured during the 12-month prior to the year of acquisition. The valuation effects are also supported by a positive effect of the difference in the country-level value-weighted market-tobook ratios between acquirer and target countries. That is, firms from countries whose currencies appreciated over the sample period are more likely to be purchasers of firms whose currency depreciated and superior equity returns and growth opportunities are likely to be indicative of lower cost of capital for the acquirer increasing the probability of cross-border transaction. Moreover, both the stock and currency return differences tend to have a larger impact on the likelihood of acquisition in situations where the acquiring country is wealthier than the target country. The currency effect also tends to be larger for country pairs for which the geographical distance between them is closer than the sample median. Finally, the effect of the valuation differences in country-level stock returns tends to be strongest when the target's country imposes constraints on capital account openness and hence the overall financial liberalization is low. Overall, the results suggest that the decision of cross-border M\&A are affected by valuation, and that valuation have the largest impact on country pairs for which cross-border M\&A are more probable for other reasons. Given that changes in valuation lead to M\&A conditional on other reasons indicate that cross-border M\&A should not be thought of as a pure financial arbitrage, as in this case the marginal effect of valuation on M\&A likelihoods would be approximately the same regardless of the countries involved. Overall, the results suggest that that the impact of valuation on probability of acquisition occurs because of the wealth effect described by Froot and Stein (1991) rather than the mispricing effect discussed by Shleifer and Vishny (2003).

The second set of factors used by Erel et. al (2012) is related to the fact that the decisions to engage in cross-border M\&A are likely to be affected by cultural differences between countries (e.g., language, religion, historical conflicts), which could increase the contracting costs involved in linking two firms across borders (e.g., Ahern et al., 2015). Nevertheless, the results reveal that sharing a common language or religion does not affect merger propensities when controlling for other factors. In fact, the common cultural background of countries could be indirectly captured by the positive effect of bilateral trade flows on cross-border M\&A.

In addition to cultural distance, geographic distance between countries involved in crossborder M\&A is also likely to affect the probability of transaction. Similar to the arguments of the "gravity" literature in international trade, physical distance can increase the costs of combining two firms (see Rose, 2000). The results in Erel et. al (2012) provide strong support for this hypothesis. Geographic proximity clearly matters and other things

equal, the shorter distance between two countries increases the likelihood of cross-border M\&A.

The empirical evidence also indicate that taxes appear to affect cross-border M\&A decisions, since acquirers are more likely to be from countries with higher corporate income tax rates than the countries in which targets are located.

Moreover, the potential for value creation through M\&A and hence the incentives to engage in transaction is also likely to be affected by corporate governance factors. For example, acquisition could increase the legal protection of minority shareholders in target firms by 
extending to them some of the rights of acquiring firms' shareholders. In general, corporate governance arguments implies that firms in countries that promote governance through better legal or accounting standards will tend to acquire firms in countries with lower-quality governance (e.g., Bris et al., 2008).

The level of market development could also affect cross-border M\&A. In that respect, developed-market acquirers are likely to obtain more benefits from weaker contracting environments in emerging markets (Chari et al., 2009). The positive effect between the quality of accounting disclosure systems of the acquirer and the target found in Erel et. al (2012) is consistent with governance arguments, because development and accounting standards are likely to be correlated with better corporate governance. The authors also investigate separately an issue related to the fact that the quality of accounting disclosure effect could be driven by the generally lower level of economic development of emerging markets included in the sample. The results for separate subsamples of developed and emerging country targets indicate that disclosure quality matters in each subsample, but the effect is indeed stronger when the target is from an emerging market.

The links between the corporate governance and cross-border M\&A is explored in greater details in Rossi and Volpin (2004). The paper studies the determinants of mergers and acquisitions around the world by focusing on differences in laws and regulation across countries. The sample includes 45,536 M\&A deals announced between January 1, 1990 and December 31, 1999 and completed as of December 31, 2001 and covers 49 countries for which empirical measures of investor protection were available at the time of the study.

The authors focus on two competing hypotheses. According to the outcome hypothesis (La Porta et al., 2000), greater legal protection for investors generates more deals and stimulates competition among bidders. The effect of higher investor protection materialises from greater availability of financial resources for the acquirer and lower acceptable prices for the targets due to lower private benefits of control of their managers and owners. The alternative governance hypothesis (Manne, 1965; Jensen, 1993) points out that the cross-border market for corporate control tends to target firms with poor governance, and hence this hypothesis predicts a negative relationship between investor protection and M\&A activity across countries.

The authors find that in general, the volume of M\&A activity is significantly larger in countries with better accounting standards and stronger shareholder protection. Similar to Erel et. al (2012), it is also found that in cross-border deals, targets typically come from countries with poorer investor protection than their acquirers' countries. The result holds when the authors control for bilateral trade, relative GNP per capita, and cultural and geographical differences. According to the authors, the result suggests that cross-border M\&A activity play an effective role in worldwide convergence in corporate governance standards (Coffee, 1999).

In particular, Rossi and Volpin (2004) find that as expected the common-law origin of the target's country reduces the likelihood of a cross-border deal, as the common-law countries tend to better protect minority shareholders than do countries with civil law (La Porta et al., 1998). They also show that raising the accounting standards and an increase in shareholder protection tend to significantly decrease cross-border deals, when the cross-border M\&A activity is measured as the number of cross-border deals as a percentage of all deals with target in each country. This suggest that cross-border M\&A play a governance role by targeting firms in countries with lower investor protection, providing support for the governance hypothesis. 
In contrast, all measures of investor protection tend to exhibit positive and significantly correlation with the M\&A activity in the cross-country relationship between overall M\&A activity and investor protection, providing evidence in favour of the outcome hypothesis.

The governance hypothesis is supported further when Rossi and Volpin (2004) study the pattern of cross-border M\&A by controlling at the same time for the characteristics of target and acquirer countries, using as the dependent variable the number of cross-country deals for each pair of countries as a percentage of the total number of deals in a target's country. According to the results, only the quality of the investor protection in the acquirer country is positively and significantly affects the volume of deals between two countries. The overall findings on the effect of shareholder protection suggest that countries with better governance standards (proxied by higher shareholder protection) export their standards to other countries via cross-border deals, and this supports the governance hypothesis. The results are also consistent with the outcome hypothesis as countries with a more developed capital market (proxied by higher accounting standards) seem to use their lower cost of capital for crossborder acquisitions. Somewhat puzzling, the effects of the investor protection variables of the target country tend to be insignificant, when the acquirer's country characteristics are controlled for.

Further evidence focusing on the difference in investor protection between acquirer and target presented in Rossi and Volpin (2004) reconfirms that that the acquirer typically has stronger investor protection than the target in cross-border M\&A. The governance hypothesis is also supported by the fact that richer countries are more likely to be acquirers and that the acquirer and target in cross-border M\&A typically share the same language, religion, and come from the same geographical area.

The cross-border M\&A originating from emerging markets are growing in importance globally as they tend to be the largest part of outward foreign direct investment (OFDI) from emerging economies which itself constitutes about one third of global OFDI flows (UNCTAD, 2014). The general perception is that international expansion of emerging market firms (EMFs) helps them to achieve important strategic objectives, such as the acquisition of technology, brand names, and natural resources (UNCTAD, 2014).

Most of the literature on the determinants of cross-border M\&A uses the global samples of firms' transactions. A study focusing specifically on examining cross-border M\&A by EMFs are rare, contradictory, and most often focus on a single country falling short of formally testing existing theories or developing comprehensive theories for emerging economies (Deng, 2013; Kothari et al., 2013). A notable exception to this is a recent paper by Deng and Yang (2015) which conducts a comparative investigation of cross-border mergers and acquisitions by emerging market firms. The authors use a sample of M\&A deals by firms from nine emerging economies which generated the highest number of transactions in 2000-2012. The countries covered are Brazil, China, India, Indonesia, Mexico, Russia, South Africa, Thailand, and Turkey.

The paper seeks to apply and extend resource dependence theory (Hillman, Withers, \& Collins, 2009) to comparatively investigate major factors that determine the level of crossborder M\&A by EMFs in developed and developing markets. The authors argue that the resource dependence logic of M\&A helps to better understand the international expansion strategies of EMFs via cross-border M\&A, but it is also conditional on institutional environment (i.e., government effectiveness) in a target's country. The authors effectively 
focus on four main hypotheses. First, the size of financial market in a target's nation is expected to positively affect the number of cross-border M\&A initiated by EMFs in both developed and developing countries (Di Giovanni, 2005; Nicholson and Salaber, 2013). Second, the natural resources of a target's country are expected to be positively associated with the number of cross-border M\&A by emerging market firms in each target's country (Pfeffer and Salancik, 2003, Gaur et al., 2014). Third, the strategic assets of a target's country, such as superior marketing expertise, product differentiation, patent-protected technology, and managerial know-how is expected to be positively related to the number of cross-border M\&A by emerging market firms in each target's country. Finally, government effectiveness of the target's country is expected to be negatively associated with the number of cross-border M\&A by emerging market firms in each target's country, and also decrease the potential effects of the target's country market size, natural resources, and strategic assets on the likelihood of a transaction (Santos and Eisenhardt, 2005; Das and Teng, 2001; Dress and Heugens, 2013).

As a dependent variable Deng and Yang (2015) use the total number of complete M\&A deals made by firms of the nine EMFs in each target's country each year. In terms of main explanatory variables, the ratio of stock market capitalization to GDP is used to represent the size of financial market, the natural resource endowment of the target's country is proxied by the ratio of ore and metal exports to merchandize exports, the total number of patent registrations (both resident and non-resident) in a target's country used as a proxy of strategic assets, while the government effectiveness of a target's country is measured by one of the six worldwide governance indicators developed by Kaufmann et al. (2010). The control variables used include the annual growth rate of GDP in acquirer's country, the total value of foreign exchange reserves in acquirer's country, the ratio of stock market capitalization to GDP in acquirer's country, the index capturing the difference between the national culture of acquiring firms and those of target firms (Kogut and Singh, 1988), and the lagged number of M\&A deals.

According to the results, factors affecting the level of cross-border M\&A by EMFs in developed markets tend to be different from those in developing markets. The effects of resource dependence on cross-border M\&A by EMFs and the moderating effects of target's government effectiveness on the M\&A intensity are fully supported in the setting of developed markets and, to some extent supported in the setting of developing markets. In particular, the effect of strategic assets is insignificant in the sample of developing markets M\&A, and government effectiveness in target's developing countries positively rather than negatively affects the relationship between the number of cross-border M\&A and the level of natural resources of target's markets. The latter result is potentially explained by the large scale of acquisitions related to natural resources where higher government effectiveness of a target's country could help to legally protect acquirer's long-term interests (Kamaly, 2007 and Peng et al., 2008).

The effects of control variables indicate that EMFs are likely to undertake more M\&A in both developed and developing markets when their home countries have bigger financial market size, have higher foreign reserves and when they undertook more acquisitions in the previous year. It also appears that EMFs are likely to undertake more M\&A in developing markets when these markets have small cultural distance with acquirer's countries.

Finally, Deng and Yang (2015) show that target's country factors attracting Chinese M\&A are different from those attracting other emerging economies. The effects of natural resources endowment, strategic assets, and market size are insignificant for Chinese M\&A in developing countries. Moreover, target's government effectiveness in both developed and 
developing countries positively rather than negatively affects the relationships between Chinese cross-border M\&A and the size of financial market, the richness of natural resources and strategic assets of developed countries. Thus, the authors conclude that one needs to be cautious in generalizing the determinants of Chinese M\&A deals to other EMFs.

Shedding more light on the findings of Deng and Yang (2015), a recent study conducted by McKinsey \& Co (Cogman et al., 2015) finds that an increasing number of emerging-market companies engage in cross-border M\&A to acquire technology, brands, and know-how. This trend represents a shift from traditional focus on acquiring strategic and natural resources.

Rather interestingly, transaction's dominant strategic motive is identified indirectly by adopting measured based on median R\&D intensity and intangible assets per industry (for asset-seeking motives), median sales growth per industry (for market-seeking motives), median staff cost per industry (for efficiency-seeking motive), and target company affiliation with natural resource industry (for natural resource-seeking motives). The industry measures for each year and each country were assigned to acquiring and target companies and the standardized difference between two companies involved was used to determine the dominant strategic motive of a deal. Out of 1,095 emerging-market cross-border acquisitions completed in 2000-2013 and covered by the study, 56 percent of companies headquartered in emerging markets try to fill capability gaps caused by limited access to strategic resources, such as technology, management capabilities, or other intangible assets in their home markets. This is compared to 37 percent of companies in developed markets $(6,9657$ acquisitions by companies from the OECD member-countries). The motive of tapping new markets and customers or sustain existing markets accounts for 14 percent of emerging markets and 18 percent of developed markets acquisitions, while securing access to natural resources, such as raw materials and energy accounts for 21 percent and 10 percent respectively. The motivation of improving efficiency by accessing production assets, such as labour, at a relatively lower cost unsurprisingly results in the largest gap with only 2 percent of emerging markets companies versus 26 percent of developed market companies.

The breakdown of the 2000-2013 period into sub-periods reveals a striking evolvement in motivation of EM companies. The proportion of deal volume motivated by strategic resources steadily decreases from 77 percent in 2000-03 to 61 percent in 2004-07, 56 percent in 2008-09, and 44 percent in 2010-13. The deals motivated by access to natural resources are on the rise throughout most of the period reaching 31 percent of the total in 2008-09 but subsequently declining to 18 percent in 2010-13. In contrast, the volume of deals motivated by access to new markets rise dramatically from under 10 percent in 2000-09 to 28 percent in 2010-13.

The least common reason for the emerging-market companies cross-border acquisitions is in pursuit of efficiency. The motivation behind these types of deals which accounts for only 4 percent of the total in 2010-13 typically includes low labour costs and specific government policies related to import barriers or investment incentives. Responding to these incentives emerging markets companies move manufacturing capacity to foreign markets by acquiring production-related companies abroad. Moreover, the growing share of efficiency-seeking M\&A by emerging-market bidders mainly flows into other emerging countries, where production factors are comparatively cheap.

The evidence of non-random selection of acquisition targets presented in some of the papers surveyed so far is further supported by Chari et al. (2012). The authors study 
acquisitions of U.S. firms by firms located in emerging markets and find that the selected U.S. targets tend to be characterised by relatively high levels of sales, employment, and total assets. This selection issue has important implications for choosing counterfactual evidence in order to appropriately compare pre- and post-acquisition performance of target firms - the issue which will be discussed in more details in the next section.

\subsection{Determinants of $M \& A$ value creation for shareholders}

The crucial issue in cross-border M\&A transactions is whether they create wealth for firms' shareholders and whether the magnitude of this wealth creation and its distribution between acquiring and target firms' shareholders is different comparing to domestic M\&A deals. From the theoretical perspective, the foreign market entry of an acquirer is likely to be driven by desire to utilise its comparative advantage in exploiting market imperfections (e.g., Buckley and Casson, 1976; Morck and Yeung, 1992; Wilson, 1980). The benefits of integrating acquirer's business with another firm are typically accrued through internalization, synergy, and risk diversification and expected to create wealth for both acquirer and target-firm shareholders (Kang, 1993; Markides and Ittner, 1994; Morck and Yeung, 1991, 1992).

Market reaction to M\&A deal announcements tend to differ for cross-border and domestic M\&A. The latter ones are typically categorised by positive returns for the seller and negative or neutral returns for the buyer, with non-existing or marginally positive combined returns (Kaplan and Weisbach, 1992; Carow, Heron, \& Saxton, 2004). It has been argued that target shareholders gain from the acquisition because of the premium paid by the acquirer (Datta, Pinches, \& Narayanan, 1992; Hansen \& Lott, 1996).

The existing evidence indicate that the cross-border M\&A are more likely to create value and produce gain for both parties involved in the transaction. For example, Morck and Yeung (1992) examined 332 foreign acquisitions by U.S. firms between 1978 and 1988 and found that the acquirer's abnormal returns were positively related to acquirer's R\&D and advertising intensity, as well as its management quality. According to the authors, these factors represented information-based resources that allowed the acquirer to effectively internalize the assets of the target.

Markides and Ittner (1994) used a sample of 276 cross-border M\&A by U.S. firms between 1975 and 1988 and found positive association between acquirer's abnormal returns and acquirer's home currency strength, prior international experience, industry advertising intensity, industry concentration, business relatedness of two firms, and the relative size of the acquirer and the target firms' business.

Harris and Ravenscraft (1991) looked at M\&A transactions where U.S. firms were the targets of foreign buyers and find that target wealth gains were significantly higher in crossborder deals than in domestic acquisitions. Foreign companies paid about 10 percentage points (about 50 percent) more than domestic firms in noncash bid and premiums were positively related to R\&D intensity of the industries, and the relative strength of the buyer's currency.

Kang (1993) studied M\&A deals of 119 Japanese firms involving 102 U.S. firms between 1975 and 1988. The results indicated that cross-border M\&A created wealth for both 
acquirer and target firm shareholders. The acquiring firms' gains were positively associated with the relative strength of their home currency, and their overall level of debt and borrowings from financial institutions, suggesting that high leverage alleviates potential agency costs (Jensen, 1986).

Datta and Puia (1995) studied shareholder value creation in 112 large cross-border M\&A transactions undertaken by U.S. firms between 1978 and 1990. In contrast to the previously reviewed studies, their results suggested that cross-border M\&A, on average, do not create value for acquiring firm shareholders. The authors also found that M\&A deals characterized by high cultural distance were associated with lower wealth effects for acquiring firm shareholders.

Manzon et al. (1994) focused on difference between tax systems of countries involved in cross-border M\&A. The authors found that U.S. acquirers' abnormal returns were higher when targets were located in high-tax countries, rather than low-tax countries. According to the authors, acquisitions that increased acquiring firms' ability to repatriate funds to U.S. resulted in a positive market reaction, while transactions that were likely to result in income that would trigger additional U.S. taxes upon repatriation resulted in an unfavourable market reaction.

Cakici et al. (1996) examined shareholder wealth gains for 195 foreign firms that acquired U.S. target firms during 1983-1992. Positive and significant abnormal returns were documented for foreign acquirers of the U.S. targets but not for the U.S. companies purchasing foreign firms. The changes in the U.S. tax code did not appear to affect gains to foreign buyers of U.S. firms. The authors also found that acquirer's abnormal returns were not affected by relative size of target to bidder, acquirer's overseas exposure, the target's R\&D intensity, industry factors or relative value of currency. The results suggested that competition among bidding firms for the same target decreases the returns to the acquirers.

In an attempt to reconcile the conflicting results of the previous research, Seth et al. (2002) analysed factors that create or destroy value in cross-border M\&A by focusing on different motives for acquisitions. The authors found that the value creating deals tend to be the ones focusing on synergies realised in combining firms' complementary assets. The documented sources of value creations were asset sharing, reverse internalization

of valuable intangible assets, and financial diversification. The value-destroying deals were the ones where managers pursued their personal interest or made mistakes in the target evaluation process.

The importance of management qualities for value-creating M\&A was reconfirmed by Servaes (1991). Using Tobin's q as a measure of managers' performance, the author found that M\&A gains were the highest when firms with high Tobin's Q acquired firms with low Tobin's Q. In other words, better performing firms were more likely to make better acquisitions and more value was created from acquiring underperforming companies.

The increasing importance of emerging markets for the global economy and the growing volume of M\&A transaction involving companies from these countries motivated a number of recent studies focusing on M\&A's performance and its determinants in emerging markets (Lebedev et al., 2015). 
Aybar and Ficici (2009) studied 433 acquisitions by multinational companies from emerging markets from 1991 to 2004 and found that abnormal returns for acquiring firms were on average negative. Nevertheless, abnormal returns were shown to be positively associated with the relative size of the target, private ownership of the target, and diversification motives of transactions. The value destruction was observed when the acquirer was from high-tech industry or the industry similar to a target. Consistent with the results of previous studies (FeitoRuiz and Menendez-Requejo, 2011), the institutional development of a target's country was found to have a positive effect on abnormal returns for acquiring firms.

Gubbi et al. (2010) studied performance of 425 cross-border acquisitions of Indian firms between 2000 and 2007. The authors found support for the hypothesis that cross-border M\&A create shareholder value for acquiring firms. According to the authors, international acquisitions helped to internalize resources that were difficult to trade through market transactions and were costly to develop internally, suggesting an important strategic aspect of value creation for emerging-economy firms. It was also shown that the value created for acquiring firms' shareholders was greater when the target firms were located in advanced economic and institutional environments.

Bhagat, Malhotra, and Zhu (2011) looked at 698 cross-border acquisitions made by firms from emerging markets from 1991 to 2008 . The authors documented positive abnormal returns for acquirers on the announcement day. The acquiring firms returns were positively related to the quality of corporate governance in the target country, suggesting that the acquirers voluntarily 'bootstraps' themselves to the higher governance standards of the target (Martynova and Renneboog, 2008; Khanna and Palepu, 2004).

Nicholson and Salaber (2013) studied 203 Indian and 63 Chinese cross-border deals over the period 2000-2010 and found evidence of significant shareholder wealth creation for acquiring firms. The authors found that Indian shareholders' gains were positively affected by small cultural distance with targets' countries, while Chinese investors benefited from the cross-border enlargement of manufacturing companies. Similar to the previously reviewed studies, acquisitions of firms from developed countries generated higher returns to shareholders.

Chari et al. (2010), analysed 594 cross-border M\&A deals from 1986 to 2006, where a developed-country multinational firm acquired majority control of a firm in an emerging market. The authors found that developed-market acquirers experienced positive and significant abnormal returns over a three-day event window and these abnormal returns for the same acquires were not observed when their targets were from the developed countries. The abnormal returns were found to be higher in the weaker contracting environment in the emerging market and in industries with high proportion of intangible assets.

Chari et al. (2012) study changes in the performance of U.S. firms acquired by firms from emerging markets. The authors document significant improvements in the postacquisition stock market and accounting-based measures of performance of publicly listed U.S. targets. Nevertheless, the presented evidence highlights the importance of selecting an appropriate matched sample of control firms that were not acquired in order to correctly evaluate the changes in targets' post-acquisition performance by separating casual and selection effects in M\&A. The propensity score matching approach employed to group together relatively similar acquired and non-acquired firms results in the 47-99 percent reduction in the bias for observable covariates. That is, the difference of means of selected covariates (e.g., 
sales, assets, employment, net income, debt, firm-age) between the two groups becomes statistically insignificantly only after implemented matching procedure, which in turn allows to appropriately evaluate changes in post-acquisition performance and the effects of restructuring measures. The empirical results based on propensity score matching and difference-in-difference approach indicate an increase in profitability and efficiency improvements of acquired firms in line with the set hypothesis. The authors also document the positive and significant announcement period abnormal returns for the targets in the range of 8.9-9.7 percent, which is lower than what tends to be observed in domestic U.S. M\&A (Andrade, Mitchell, and Stafford, 2001).

\subsection{Conclusions}

The studies of the cross-border M\&A deals only recently received rigorous attention in academic research. In this survey, we summarise the existing evidence on factors determining the cross-border M\&A activities and look at whether cross-border M\&A transactions tend to create wealth for firms' shareholders. A particular attention is paid to the evidence from the emerging markets, which became an increasingly important arena for M\&A, in line with their growing role in the global economy. The dynamic and changing environment of the M\&A activities of the emerging markets firms is clearly represented by a documented recent trend indicating a shift from traditional focus on acquiring strategic and natural resources towards acquisition of technology, brands, and know-how. The existing empirical evidence highlights unique challenges represented by the cross-border M\&A deals which tend to involve firms from the countries with different economic, institutional, and cultural environments.

The reviewed papers also provide strong evidence with respect to non-random selection of acquisition targets, which, among other "selection issues", has important implications for choosing counterfactual evidence in order to appropriately compare pre- and post-acquisition performance of firms. A number of researches acknowledged that the empirical corporate takeover literature is plagued with largely unresolved econometric issues of endogeneity and self-selection, but corrections for self-selection are still relatively seldom discussed and implemented in empirical tests (e.g., Betton et al., 2008; Ahern, 2009; Chari et al., 2012; Nivorozhkin et al., 2014). More research is this area is clearly warranted and it would likely to have important implications on the existing results in the literature.

While following distinct wave patterns over time, the likelihood of the cross-border M\&A deals tend to be positively (or non-negatively) related to the attractive valuation of the target companies, more developed capital market of an acquirer's country relative to a target's country, geographical proximity between countries, and lower cultural differences between countries. The corporate governance factors also tend to play an important role. A weaker contracting environment of a target's country tends to increase the propensity of M\&A deal involving a developed country's acquirer. To this extent, it appears that M\&A activity tends to play an effective role in worldwide convergence in corporate governance standards. Nevertheless, when emerging market firms acquire firms in a developing country, the corporate governance proxies tend to have a positive effect on the number of M\&A deals, particularly when conditional on some control variables, such as the industry of an M\&A deal.

The cross-border M\&A appear to be more likely to create value and produce gain for both parties involved in the transaction comparing to the domestic M\&A. As the type of factors increasing the value enhancing effects tend to be similar to the factors affecting the likelihood 
of M\&A transactions listed earlier, we again emphasise the importance of using an appropriate matched sample of control firms that were not acquired in order to correctly evaluate the changes in post-acquisition performance by separating casual and selection effects. 


\section{References}

Ahern, K. (2009). Sample selection and event study estimation, Journal of Empirical Finance, $16,466-482$.

Andrade, G., Mitchell, M., and E. Stafford (2001). New Evidence and Perspectives on Mergers. Journal of Economic Perspectives 15 (2), 103-120.

Ahern, Kenneth, Daniele Daminelli, and Cesare Fracassi (2015). Lost in translation? The effect of cultural values on mergers around the world, Journal of Financial Economics 117 (1), Pages $165-189$

Aybar, B., and A., Ficici (2009). Cross-border acquisitions and firm value: An analysis of emerging-market multinationals. Journal of International Business Studies 40(8),

$1317-1338$.

Bannock, G. (1990). The Takeover Boom: An International and Historical Perspective, Hume Occasional Papers, Edinburgh: The David Hume Institute.

Betton, S., E. Eckbo, and K. Thorburn (2008). Corporate takeovers, in E. Eckbo (ed.), Handbook of Corporate Finance: Empirical Corporate Finance, Vol. 2. Ch. 15, Elsevier.

Bhagat, S., Shleifer, A., and R.W., Vishny (1990). Hostile takeovers in the 1980s: The return to corporate specialisation, Brookings Papers on Economic Activity: Microeconomics, 172 .

Bhagat, S., Malhotra, S., and P. C., Zhu (2011). Emerging country cross-border acquisitions:

Characteristics, acquirer returns and cross-sectional determinants. Emerging Markets Review $12,250-271$.

Bris, Arturo, Neil Brisley, and Christos Cabolis (2008). Adopting better corporate governance: Evidence from cross-border mergers, Journal of Corporate Finance 14, 224-240.

Buckley, P., and M., Casson (1976). The Future of Multinational Enterprise. Macmillan, London.

Cakici, N., Hessel, C., and K., Tandon (1996). Foreign acquisitions in the United States: effect on shareholder wealth of foreign acquiring firms. Journal of Banking and Finance 20 (2), 307-329.

Carow, K., Heron, R., and T., Saxton (2004). Do early birds get the returns? An empirical

investigation of early-mover advantages in acquisitions. Strategic Management Journal, 25(6): 563-585.

Chari, Anusha, Paige Ouimet, and Linda Tesar (2009). The value of control in emerging markets, Review of Financial Studies 23, 1741-1770.

Chari, A., Ouimet, P. P., and L. L., Tesar (2010). The value of control in emerging markets. Review of Financial Studies, 23(4), 1741-1770.

Chari, A., Chen, W., and K. M. E. Dominguez (2012). Foreign ownership and firm performance: Emerging market acquisitions in the United States. IMF Economic

Review, 60(1), 1-42.

Cogman, D., Jaslowitzer, P., and M., Rapp (2015). Why emerging-market companies acquire abroad. McKinsey \& Company (available at http://www.mckinsey.com/businessfunctions/strategy-and-corporate-finance/our-insights/why-emerging-market-companiesacquire-abroad)

Das, T. K., and B., Teng (2001). Trust, control, and risk in strategic alliance: An integrated framework. Organization Studies, 22(2), 251-283.

Datta, D., and G., Puia (1995). Cross-border acquisitions: an examination of the influence of relatedness and cultural fit on shareholder value creation in U.S. acquiring firms. Management International Review 35, 337-359.

Deng, P. (2013). Chinese outward direct investment research: Theoretical integration and recommendations. Management and Organization Review, 9(3), 513-539. 
Deng, P., and M., Yang (2015) Cross-border mergers and acquisitions by emerging market firms: A comparative investigation. International Business Review 24, 157-172.

Di Giovanni, J. (2005). What drives capital flows? The case of cross-border M\&A activity and financial economies. Economic Systems, 28, 281-300.

Dress, J., \& Heugens, P. (2013). Synthesizing and extending resource dependence theory: A meta-analysis. Journal of Management, 39(6), 1666-1668.

Erel, I., Liao, R., Weisbach, M. (2012). Determinants of cross-border mergers and acquisitions. Journal of Finance 67, 1031-1043.

Feito-Ruiz, I., and S., Menendez-Requejo (2011). Cross-border mergers and acquisitions in different legal environments. International Review of Law and Economics 31, 169-187.

Froot, Kenneth A., and Jeremy C. Stein (1991). Exchange rates and foreign direct investment: An imperfect capital markets approach, Quarterly Journal of Economics 106, 1191-1217.

Gaur, A. S., Kumar, V., \& Singh, D. (2014). Institutions, resources, and internationalization of emerging economy firms. Journal of World Business, 49(1), 12-20.

Gort, M. (1969). An economic disturbance theory of mergers, Quarterly Journal of Economics $11,241-273$.

Gilson, R., \& Black, B. (1995). The Law and Finance of Corporate Acquisitions. Foundation Press.

Gubbi, S. R., Aulakh, P. S., Ray, S., Sarkar, M. B., and Chittoor, R. (2010). Do international acquisitions by emerging-economy firms create shareholder value? The case of Indian firms. Journal of International Business Studies 41(3), 397-418.

Hansen, R. G., and J. R., Lott (1996). Externalities and corporate objectives in a world with diversified shareholder consumers. Journal of Financial and Quantitative Analysis, 31(1), 4368.

Harris, R.S., and D., Ravenscraft (1991). The role of acquisitions in foreign direct investment: evidence from the U.S. stock market. Journal of Finance 46, 825-844.

House, R., Javidan, M., Hanges, P., Dorfman, P., 2002. Understanding cultures and implicit leadership theories across the globe: an introduction to project GLOBE. Journal of World Business 37 (1), 3-10.

Hofstede, G. (1980). Culture's Consequences: International Differences in Work-Related Values. Sage, Beverly Hills, CA.

Hillman, A., Withers, M., \& Collins, B. (2009). Resource dependence theory: A review.

Journal of Management, 35, 1404-1427.

Hitt, M.A. (2000). The new frontier: transformation of management for the new millennium. Organizational Dynamics 28 (3), 6-17.

Jensen, M.C. (1986). Agency costs of free cash flow, corporate finance and takeovers. American Economic Review 76, 323-329.

Jensen, M. (1997). The modern industrial corporation, exit and the failure of internal control systems, in D. H. Chew (Ed.), Studies on International Corporate Finance and Governance Systems, New York: Oxford University Press.

Kamaly, A. (2007). Trends and determinants of mergers and acquisitions in devel-

oping countries in 1990. International Research Journal of Finance and Economics 8, 16-30.

Kang, J. (1993). The international market for corporate control. Journal of Financial Economics 34, 345-371.

Kaplan, S.N., and M.S., Weisbach (1992). The success of acquisitions: evidence from divestitures. Journal of Finance 47, 107-138.

Kaufmann, D., Kraay, A., \& Mastruzzi, M. (2010). The worldwide governance indicators:

Methodology and analytical issues. Retrieved from http://info.worldbank.org/governance/wgi

Kothari, T., Kotabe, M., \& Murphy, P. (2013). Rules of the games for emerging market

multinational companies from China and India. Journal of International Management, 
19, 276-299.

Kogut, B., \& Singh, H. (1988). The effect of national culture on the choice of entry mode. Journal of International Business Studies, 19, 411-432.

Khanna, T., and K., Palepu (2004). Globalization and convergence in corporate governance:

Evidence from Infosys and the Indian software industry. Journal of International Business Studies 35(6), 484-507.

KPMG (2016). Cross-Border Deals Tracker. March 2016.

La Porta, Rafael, Florencio Lopez-de-Silanes, Andrei Shleifer, and Robert W. Vishny, (1998). Law and finance. Journal of Political Economy 101, 678-709.

La Porta, Rafael, Florencio Lopez-de-Silanes, Andrei Shleifer, and Robert W. Vishny. (2000). Agency problems and dividend policies around the world. Journal of Finance 55, $1-33$.

Lebedev, S., Peng, M. W., Xie, E., and C. E., Stevens (2015). Mergers and acquisitions in and out of emerging economies. Journal of World Business 50, 651-662.

Manzon, G.B., Sharp, D.J., and, N.G., Travlos (1994). An empirical study of the consequences of U.S. tax rules for international acquisitions by U.S. firms. Journal of Finance 49, $1893-$ 1904.

Markides, C.C., and C.D., Ittner (1994). Shareholder benefits from corporate international diversification: evidence from U.S. international acquisitions. Journal of International Business Studies 25, 343-367.

Martin, X., Swaminathan, A., and W., Mitchell (1998). Organizational evolution in the interorganizational environment: incentives and constraints on international expansion strategy. Administrative Science Quarterly 43, 566-601.

Martynova, M., and L., Renneboog (2008). Spillover of corporate governance standards in cross-border mergers and acquisitions. Journal of Corporate Finance 14(3), 200-223.

Mitchell, M. L., and J. H., Mulherin (1996). The impact of industry shocks on takeover and restructuring activity, Journal of Financial Economics 41, 193-229.

Morck, R., and B., Yeung (1991). Why investors value multinationality. Journal of Business 64, 165-187.

Morck, R., and B., Yeung (1992). Internalization: an event study test. Journal of International Economics 33, 41-56.

Nicholson, R. R., and J., Salaber (2013). The motives and performance of cross-border acquirers from emerging economies: Comparison between Chinese and Indian firms. International Business Review 22(6), 963-980.

Nivorozhkin, E., Holmen, M, and Rana, R. (2014). Do antitakeover devices affect the takeover likelihood or the takeover premium? The European Journal of Finance, 20 (4), 319-340.

Peng, M. W., Wang, D. Y., and Y., Jiang, (2008). An institution-based view of international business strategy: A focus on emerging economies. Journal of International Business Studies, 39, 920-936.

Pfeffer, J., and G., Salancik (2003). The external control of organizations: A resource dependence perspective (2nd ed.). Standard, CA: Stanford University Press.

Rose, Andrew K. (2000) One money, one market: Estimating the effect of common currencies on trade, Economic Policy 30, 7-45.

Rossi, Stefano, and Paolo F. Volpin (2004). Cross-country determinants of mergers and acquisitions, Journal of Financial Economics 74, 277-304.

Santos, F. M., \& Eisenhardt, K. M. (2005). Organizational boundaries and theories of organization. Organization Science, 16, 491-508.

Schoenberg, R., and R., Reeves (1999). What determines acquisition activity within an industry? European Management Journal, 17(1), 93-98.

Servaes, H. (1991). Tobin's Q and the gains from takeover. Journal of Finance 46, 409-419. 
Seth, A., Song, K.P., R.R., Pettit (2002). Value creation and destruction in cross-border acquisitions: an empirical analysis of foreign acquisitions of U.S. firms. Strategic Management Journal 23, 921-940.

Shimizu, K., Hitt, M., Vaidyanath, D., and V., Pisano (2004). Theoretical foundations of crossborder mergers and acquisitions: A review of current research and recommendations for the future. Journal of International Management 10, 307-353.

Shleifer, A. and R.W., Vishny (1991). Takeovers in the '60s and the '80s: Evidence and implications, Strategic Management Journal 12, 51-59.

Shleifer, A., and R. W. Vishny (2003). Stock market driven acquisitions, Journal of Financial Economics 70, 295-311.

Sudarsanam, S. (2003). Creating value from mergers and acquisitions: The challenges: An integrated and international perspective. Pearson Education.

UNCTAD (2014). World investment report 2014: Investing in the SDG: An action plan. New York, Geneva: UNCTAD.

Wilson, B.D. (1980). The propensity of multinational companies to expand through acquisitions. Journal of International Business Studies 11, 59-64. 